\title{
8
}
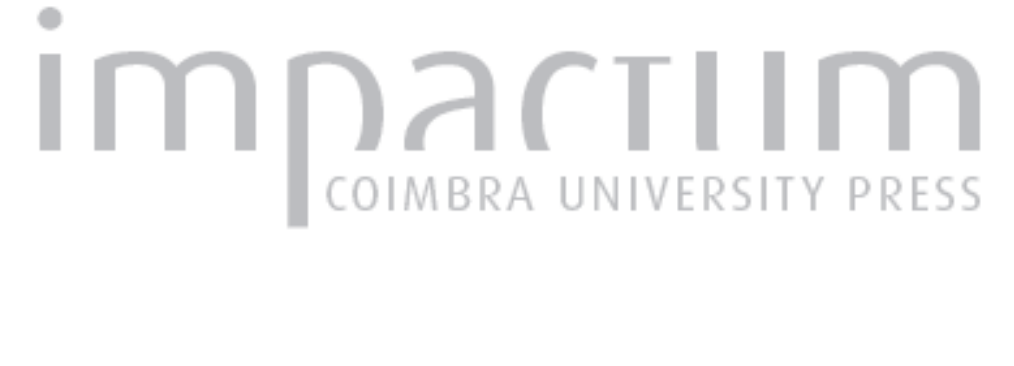

\section{Performances and standards against the global and current proliferation of counterfeit medicines}

Autor(es): $\quad$ Castillo Rodríguez, Carlos del Publicado por: Centro de Informação Europe Direct de Aveiro; Centro de Estudos

URL

persistente:

DOI: DOI:http://dx.doi.org/10.14195/1647-6336_14_11

Accessed : $\quad$ 26-Apr-2023 16:05:18

A navegação consulta e descarregamento dos títulos inseridos nas Bibliotecas Digitais UC Digitalis, UC Pombalina e UC Impactum, pressupõem a aceitação plena e sem reservas dos Termos e Condições de Uso destas Bibliotecas Digitais, disponíveis em https://digitalis.uc.pt/pt-pt/termos.

Conforme exposto nos referidos Termos e Condições de Uso, o descarregamento de títulos de acesso restrito requer uma licença válida de autorização devendo o utilizador aceder ao(s) documento(s) a partir de um endereço de IP da instituição detentora da supramencionada licença.

Ao utilizador é apenas permitido o descarregamento para uso pessoal, pelo que o emprego do(s) título(s) descarregado(s) para outro fim, designadamente comercial, carece de autorização do respetivo autor ou editor da obra.

Na medida em que todas as obras da UC Digitalis se encontram protegidas pelo Código do Direito de Autor e Direitos Conexos e demais legislação aplicável, toda a cópia, parcial ou total, deste documento, nos casos em que é legalmente admitida, deverá conter ou fazer-se acompanhar por este aviso.

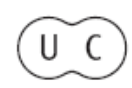


DEBATER

A EUROPA

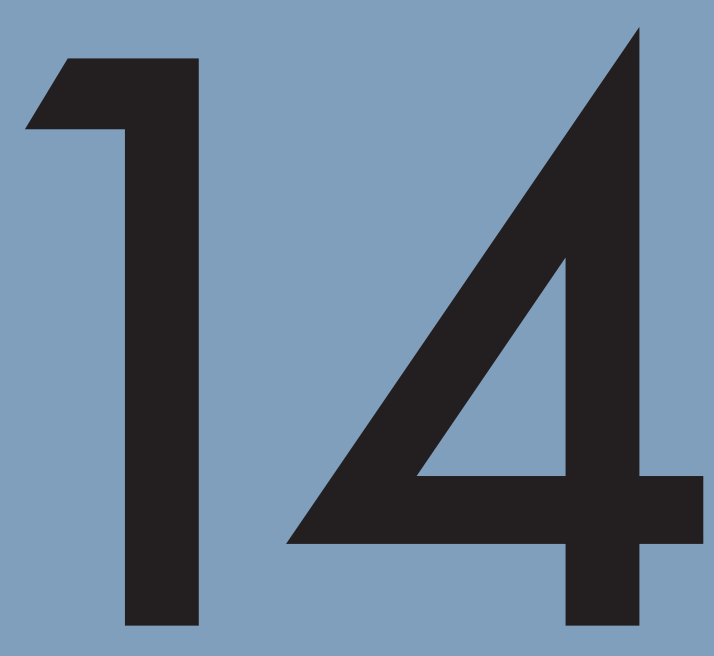

jan-jun 2016

EUROPA, FARMÁCIA, MEDICAMENTOS

EUROPE, PHARMACY, MEDICINES 


\title{
Performances and Standards against the Global and Current Proliferation of Counterfeit Medicines
}

\author{
Prof. Dr. Carlos del Castillo Rodríguez \\ School of Pharmacy. Universidad Complutense de Madrid \\ E-mail: carlcast@ucm.es
}

\section{Resumo}

A contrafação de medicamentos é um problema emergente na sociedade atual, com eventual impacto na economia da saúde e no plano jurídico. Esta questão tem causado alterações significativas nas questões relacionadas com os medicamentos falsificados e sua relação com o sistema jurídico espanhol, em conformidade com a legislação comunitária e internacional. Eficácia, qualidade e segurança dos medicamentos dependem de vários elementos. Estes estão relacionados com as diversas etapas da problemática do medicamento como é o caso da investigação e desenvolvimento sobre um princípio activo e posteriores processos de fabrico, controlo de qualidade, distribuição, comunicação de informação aos profissionais de saúde, prescrição, dispensa do medicamento, adesão ao tratamento e farmacovigilância. Em cada um destes níveis, pode haver conflitos de interesses entre os grupos envolvidos. Muitas vezes o paciente paga as consequências dessas divergências. É o caso de falsificação de medicamentos. Neste caso o produto final é deliberadamente obtido de modo fraudulento. A contrafação pode ser feita tanto em medicamentos de marca como em medicamentos genéricos. A contrafação pode ser feita com as matérias-primas certas, com matérias-primas diferentes das originais, sem princípios ativos ou com princípios ativos insuficientes ou em excesso. A embalagem também é falsa. A falsificação de medicamentos constitui um problema de saúde em países desenvolvidos ou em desenvolvimento. No presente estudo analisamos este problema e soluções eficazes para tentar resolver a proliferação da contrafação de medicamentos, tanto a nível europeu e internacional.

Palavras-chave: medicamento; farmácia; fraude; Internet 


\begin{abstract}
Counterfeit medicines are an emerging problem in today's society as well as its possible impact on health, legal and today's economy. This issue has caused a significant change in the aim's view of the origin and development of counterfeit medicines and its relationship with the Spanish legal system in accordance with EU and international law. Efficacy, quality and safety of medicines depend on several elements present in traceability or in their life, such as research and development of an active ingredient or appropriate pharmaceutical agent, manufacturing, quality control, distribution, testing requirements, reliable information for health professionals, diagnosis, prescription, medicine dispensation, treatment compliance and pharmacovigilance. At each level, conflicts of interests among the groups involved arise, and in many occasions, the patient pays the consequences of these divergences. This is the case of counterfeit medicine, since it is a product deliberately and fraudulently mislabeled with respect to its identity or its source. Counterfeiting can be made in both branded and generic medicines, with the correct ingredients or with the wrong ingredients, without active ingredients, with insufficient or too much active ingredient, or with fake packaging. Counterfeiting practice is a major cause of morbidity and mortality in both developing and developed countries. In the present work we analyse this problem and how effective solutions have been developed to try solving such proliferation both at European and international level.
\end{abstract}

Keywords: medicine; Pharmacy; fraud; Internet

\title{
1. Introduction
}

In general terms, and except special cases, all of us yearn for being healthy, but we should talk about the social dimension, not only understood health as the absence of disease, but as synonym of well-being. In our view, nothing has contributed so much to human well-being as medicines ${ }^{1}$.

Medicines are elements that have contributed to historical demographic changes, not only reducing mortality and increasing life expectancy, but also improving lives of

\footnotetext{
${ }^{1}$ BASANTE POL, R.; CASTILLO RODRÍGUEZ, C. Financiación de medicamentos: los aspectos jurídicos. Anales de la Real Academia Nacional de Farmacia. Madrid: Real Academia Nacional de Farmacia. 2013, 2(79): 294.
} 
millions of people in the world ${ }^{2}$. In order to obtain medicines are required scientific and technological foundations, whose minimum denominator is designing, elaboration, storage and dispensing, for this activity is necessary an acurate knowledge of various physico-chemical and natural sciences as well as sophisticated technology for preparing medicines and therefore for establishing a collaboration between maintaining and restoring living beings' health ${ }^{3}$.

Currently there is a large consumption/demand for medicines in developed countries led by the "marketing of fear", producing a "breeding ground" that on many occasions causes counterfeit medicines in certain areas.

The feeling of insecurity is a constant among members of a society, being the use of medicines particularly sensitive to such mood.

We should remember that Spanish legal system, according to European Community guidelines, defines medicinal products for human use ${ }^{4}$ as "any substance or combination of substances presented with properties for treating or preventing diseases in human beings or which can be used in humans or administered to human beings in order to restor, correct or modify physiological functions by exerting a pharmacological, immunological or metabolic action, or by making a medical diagnosis". The same guideline, published just two months ago, establishes a closed list of legally recognized medicines (Article 8):

- Medicinal products for human and veterinary use, industrially processed or manufactured by an industrial process

- Pharmaceutical compounding

- Officinal preparation

- Special medicines provided by this Law ${ }^{5}$

\footnotetext{
${ }^{2}$ ESTEVA DE SAGRERA, J. Historia de la Farmacia. Los medicamentos, la riqueza y el bienestar. Barcelona: Ed. Masson, 2005.

3 PUERTO SARMIENTO, J. El Mito de Panacea. Compendio de Historia de la Terapéutica y de la Farmacia. Aranjuez (Madrid): Ed. Doce Calles S.L., 1997, pág. 10.

${ }^{4}$ Real Decreto Legislativo 1/2015, de 24 de julio, por el que se aprueba el texto refundido de la Ley de garantías y uso racional de los medicamentos y productos sanitarios. Boletín Oficial del Estado de 25 de julio de 2015, núm. 177.

${ }^{5}$ Special drugs called those with a "special" treatment by the legislator in regulating their quality, safety and efficacy. Within this diverse group, we can find radiopharmaceuticals human medicines, medicinal products derived from blood and human plasma ( blood products ), immunological human medicines , homeopathic medicinal or industrial manufacturing, medical gases, the narcotics and psychotropic drugs, herbal medicines and advanced therapy. BOMBILLAR SÁENZ, F.M. (2010). Intervención administrativa y régimen jurídico del medicamento en la Unión Europea. Tesis doctoral. Granada: Ed. Universidad de Granada, 2010, p. 243.
} 
Nowadays, both marketing of products and the use of substances are significant. The possible adverse drug reactions are not known with certainty and, in any case, these will appear years after the action is performed, for example, the case of some medicines marketed in which, after years of pharmacovigilance, some adverse, unforeseen and unexpected reactions were detected at the time the drug obtained marketing authorization (taking into account the scientific status at that time by the Medicines Agency of the country concerned $)^{6}$.

Overall, both the insecurity and the uncertainty in the post-industrial societies ${ }^{7}$ are senses or feelings of citizenship rather than a true reality since in today's society it has been spread an exaggerated sense of insecurity, which does not seem to correspondence with such risks, but it is enhanced by the vast media coverage of hazardous or harmful events, because of the difficulties encountered by the average citizen to understand the rapid scientific and technological change and the need to adjust their daily lives to the change ${ }^{8}$.

In the pharmaceutical field we can state that pharmaceutical laboratories have marketed medicines almost for "everything", making even " healthy" people potential consumers of medicines. Some critical sectors go so far as to assert that pharmaceutical industry itself has invented or sponsored diseases as the best marketing method called "the marketing of fear"" .

This paper does not intend to enter into debate, but true or not, it is apparent that nowadays the commercialization of medicines has exponentially increased. It is in this uncertain situation where healthcare professionals (and especially pharmacists) are responsible for "actively participating in projects that can benefit people's health and well-being in situations of health and disease, especially in the field of disease prevention, health education, research and exchange of information with other professionals and health authorities to better guarantee these purposes" $" 10$.

That is why, in this context, the pharmacist, as the major specialist in

\footnotetext{
${ }^{6}$ SILVA SÁNCHEZ, J. La expansión del Derecho penal. Madrid: Civitas Ediciones S.L., 2001, p. 16.

${ }^{7}$ LLAMAZARES GÓMEZ, O. Reflexiones sobre la sociedad posindustrial. Revista de Obras Públicas. Madrid: ROP, 1981, 4: 265-269.

${ }^{8}$ DÍEZ RIPOLLÉS, J. De la sociedad del riesgo a la seguridad ciudadana: un debate desenfocado. Revista Electrónica de Ciencia Penal y Criminología. 2005, (7 de enero): 4.

${ }^{9}$ JARA, M. El negocio más repugnante, el marketing del miedo. El otro País, 2 de marzo de 2010.

${ }^{10}$ Ley 44/2003, de 21 de noviembre de 2003, de ordenación de las profesiones sanitarias. Boletín Oficial del Estado de 22 de noviembre de 2003, núm. 280.
} 
medicines ${ }^{11}$, has to inform and warn society about possible irrational use of medicines ${ }^{12}$ and, in some occasions, about the danger of buying medicines via online since in many cases these can be manipulated. Consequently, in that situation of insecurity and ignorance, the patient easily access to medicines and they are sometimes altered.

\section{International proposals: A legal harmonization attempt}

There are several initiatives in trying to eradicate counterfeit medicines. Most of these proposals have been studied and analyzed in various works ${ }^{13}$. In this study we will analyze two of them, which from our point of view are the most innovative and important from the existing regulatory framework.

\subsection{Definition of counterfeit medicine in an international field}

The problem of counterfeit medicines was first addressed in the international level in 1985 at the Conference of Experts on Rational Use of Drugs in Nairobi ${ }^{14}$. After that meeting it became clear that there was a serious global concern about counterfeit medicines. For this reason, WHO, together with other international and nongovernmental organizations, thought about establishing an institution to collect data and inform governments about the nature and degree of counterfeit.

In 1988, the World Health Assembly adopted WHA41.16 resolution ${ }^{15}$. In that resolution it was requested undertaking programs for the prevention and detection of the export, import and smuggling of pharmaceutical preparations falsely labelled, counterfeit or without the required quality standards. These facts can be considered the base of counterfeit medicines definition.

All these actions were the precedents for the celebration, from 1 to 3 April 1992, in Geneva, of the first international meeting on counterfeit medicines organized by

\footnotetext{
${ }^{11}$ Vid Supra Art.6.

12 FIGUERAS, A. Dificultades para el uso racional de medicamentos. Rev Peru Med Exp Salud Pública. Lima: Instituto Nacional de la Salud. 2009,26(4): 549-552.

13 Castillo Rodríguez, C. Medicamentos falsificados: un riesgo para la salud pública. Su estudio normativo. Trabajo de Fin de Máster Oficial en Derecho Sanitario, Bioética y Derecho a la Salud en la Unión Europea. Universidad de Granada. 2015.

${ }^{14}$ World Health Organitation. The Rational Use of Drugs. Report of the Conference of Experts. (Nairobi, 25-29 November 1985). Geneve (Switzerland): WHO, 1987.

${ }_{15}$ World Health Organitation Organización Mundial de la Salud. Rational Use of Drugs. World Health Assembly Resolution WHA4 1.16. Ginebra (Suiza): WHO, 2009.
} 
WHO and the International Federation of Pharmaceutical Manufacturers \& Associations (IFPMA $)^{16}$. After the meeting a first definition about counterfeit medicines, later modified, was developed. Spurious/falsely-labelled/falsified/counterfeit (SFFC) medicines are medicines that are deliberately and fraudulently mislabelled with respect to identity and/or source. As we have just mentioned, counterfeiting can be applied to both branded and generic products and medicines may include products with the correct ingredients or with the wrong ingredients, without active ingredients, with insufficient or too much active ingredient, or with fake packaging.

However, a simple definition of this issue did not prevent the progressive growth of these products in the international field. It is for this reason why, during the celebration of the World Health Assembly in 1994, the WHA47.13 resolution was implemented. In this resolution the executive director of WHO was called to assist Member States in their efforts to ensure that available medicines are of good quality, and to combat the use of counterfeit medicines ${ }^{17}$.

In 1998, the World Health Organization ${ }^{18}$ published a work about this matter stating that Spurious/falsely-labelled/falsified/counterfeit (SFFC) medicines are "medicines that are deliberately and fraudulently mislabelled with respect to identity and/or source. Counterfeiting can be applied to both branded and generic products and medicines may include products with the correct ingredients or with the wrong ingredients, without active ingredients, with insufficient or too much active ingredient, or with fake packaging. Use of SFFC medicines can result in treatment failure or even death in both developing and developed countries."

As a result of the continuing even increasing risk of counterfeit medicines for public health in the distribution chains of medicines, the International Pharmaceutical Federation (FIP) approved a statement ${ }^{19}$ entitled Ensuring Quality and Safety of Medicinal Products to Protect the Patient. FIP gives priority to the need for effective regulatory safeguards to ensure that the patient is protected from the hazard to health of

\footnotetext{
16 World Health Organitation. The Counterfeit Drug, report of a WHO/IPMA. Workshop. Geneve (Switzerland): WHO, 1992.

${ }^{17}$ World Health Organitation. Implementation of WHO'S Revised Drug Strategy: Rational Use of Drugs; and WHO'S Action Program on Essential Drugs. World Health Assembly Resolution WHA47.13. Geneve (Switzerland):WHO, 1994.

${ }^{18}$ World Health Organitation Medicamentos falsificados. Pautas para la formulación de medios para combatir los medicamentos falsificados. Geneve (Switzerland)WHO, 1998.

${ }^{19}$ FIP Policy About

FakeDrugs.[Online]:http://www.fip.org/www/uploads/database_file.php?id=167\&table_id. [ Date of reseach: 21 de junio de 2015].
} 
poor quality, substandard and counterfeit medicines. In addition, this statement adds, as innovation, the term impurity to their possible harmful and toxic effects.

Subsequently, there were further attempts of definitions similar to the ones abovementioned. It was not until late 2007, when the working group IMPACT (International Medical Products Anti-Counterfeiting Tasforce) created by WHO, prepared a document (approved in Lisbon on 12 December 2007) in which included the principles and elements to improve universal basic legislation on the subject as well as a clear definition of counterfeit medicines ${ }^{20}$. Thus, it was said that counterfeit medicines have "false representation of their identity in a fraudulent and deliberate way (including any misleading statement with respect to name, composition, strength, or other elements) and/or source (including any misleading statement with respect to manufacturer, country of manufacturing, country of origin, marketing authorisation holder regarding the manufacturer, country of manufacture, country of origin, the licensee marketing or distribution chain".

This working group, however, does not consider counterfeit medicines those which appear in a country where they are not authorized. In addition, this definition does not include medicines called "low quality and substandard", since it believes that they are legitimate medicines manufactured by laboratories, but do not meet the requirements of WHO. According to the mentioned organization, medicines must be produced in accordance with Good Laboratory Practice (Good Manufacturing Practices for Pharmaceutical Products or GMP), which are a set of procedures to ensure the quality of medicines, based on various international recommendations, on the application of scientific, technical and administrative principles that ensure uniform and controlled operation in laboratories of quality control in both management and implementation of everyday activities.

Unfortunately in today's world there are countries that can not guarantee technological, financial or human resources to develop these international standards. The undesirable phenomenon of counterfeit and substandard medicines is a current topic; but before investigating and exposing examples of these medicines, it is advisable to identify and differentiate one from another.

Counterfeit medicines have already been defined above, but in short, would be those that imitate the real ones; on the other hand, the substandard medicines are those

\footnotetext{
${ }^{20}$ IMPACT. The View of Pharmaceutical Manufacturers. International Conference on Combating Counterfeit Drugs. 2007.
} 
produced with little or without attention to the Good Manufacturing Practices. Poor quality may be accidental, with no intention of any fraud, but instead, continuous failures in production may have harmful consequences. This was the famous case of acetaminophen syrup which was contaminated during the production process by mistake, and killed more than fifty people ${ }^{21}$. Another event similar to the previous one occurred in 1995 in the African country of Niger ${ }^{22}$ during a meningitis epidemic, where after receiving the donation of eighty-eight thousand vaccines from pharmaceutical companies, it was showed "a posteriori" that initial vaccinations had been replaced by fake products; consequently around sixty thousand people were inoculated with fake vaccines and medical alert was spread all over the African continent. After this fact, a legal process began for counterfeiting medicines ${ }^{23}$.

This problem is obviously of greater magnitude in developing countries, where no specific sections on the bodies and security forces of the State, aimed at the fight against counterfeiting and piracy, including medicines. Customs surveillance together with the collaboration among different institutions such as police, laboratories and the various governments is an initiative that has yielded fruits in developed countries, but unfortunately has not been undertaken in developing countries ${ }^{24}$.

\subsection{Definition of counterfeit medicines at European context}

In parallel with the term of counterfeit medicine, developed by international organizations, regional initiatives emerge. European Commission is aware of the scope of the increasing problem and, during the first months of 2008, did a public consultation on "key ideas to better protect patients against the risk of counterfeit medicines". This institution published in December 2008 a proposal for an amending Directive 2001/83/EC as regards the prevention of the entry into the legal supply chain of medicines which are falsified in relation to their identity, history or source. The

\footnotetext{
${ }^{21}$ O'BRIEN, K.L.; SELANIKIO, G.D.; HECDIVERT, C., et al. Epidemic of Pediatric Deaths from Acute Renal Failure Caused by Diethylene Glycol Poisoning. JAMA. New York: Journal of the American Medical Association, 1998, 279: 1175-1180.

${ }^{22}$ PINEL, J.; VARAINE, F.; MARCHANT, G. Des faux vaccins anti-meningocoque lords dúne epidemia de meningite au Niger. Med Maladies Infect Journal. Paris: SPILF, 1997, 27: 561-568.

${ }^{23}$ World Health Organitation.(1995). Fake Drugs: Scourge on the System. WHO Drug Inf. Geneve (Switzerland): WHO.1995, 9: 127-129.

${ }^{24}$ La venta de medicamentos en Internet: riesgo de falsificaciones. Farmacéuticos2009 October. 350: 53 61.
} 
Commission elaborated a proposal to amend the current pharmaceutical legislation in respect to the measures against counterfeit medicines. The proposal is based on Article 95 of the Treaty and amending Directive 2001/83/EC. For this reason The Law 10/2013 was published the July $24^{\text {th }}$ according the European Legislation.

The aim of the proposal, as defined by the Commission, is to prevent the spread of counterfeit medicines through the legal supply chain. For this reason, they introduced additional rules related to the products, in particular on safety features for medicinal products subject to medical prescription; new rules regarding distribution and import of medicines and active pharmaceutical ingredients (API); and rules regarding the quality of manufacturing and the authenticity of the API abovementioned.

This modification includes:

- Specify the responsibilities to be met by wholesale distributors of medicines.

- Establish mandatory inclusion of specific security devices on the packaging of medicines.

- Prohibit manipulation of safety features of the packaging.

- Obligation to both distributors of medicines and manufacturers of active ingredients to pass audits.

- Toughen standards for inspection by publishing EudraGMP data base, managed by the European Medicines Agency.

Moreover, it is worth noting that the result of these efforts was materialized later ththrough Directive 2011/62/EU of the European Parliament and of the Council of 8 June 2011 amending Directive 2001/83/EC on the Community code relating to medicinal products for human use, as regards the prevention of the entry into the legal supply chain of falsified medicinal products.

Directive 2011/62/EU was published on 1 July 2011 In the Official Journal of the European Union amending Directive 2001/83/EC in which a Community code relating to medicinal products for human use was established as regards the prevention of counterfeit medicines entry into the legal supply chain. This new Directive 2011/62/EU was incorporated into Spanish law in 2013. Its main objective was to stop the proliferation of counterfeit medicines produced in the European Union according to their identity, history and origin. According to the mentioned Directive, the problem of counterfeit medicines is certainly worrying because not only are marketed through 
illegal channels but also using legal distribution ones.

One of the newest EU legislation was the definition of falsified medicinal products, fact of great importance, since it is the first attempt to harmonize the term at European context. According to art. 1c of Directive 2011/62/EU a falsified medicinal product is "any medicinal product with a false representation of:

a) its identity, including its packaging and labelling, its name or composition as regard any of the ingredients including excipients and the strenght of those ingredients; b) its source, including its manufacturer, its country of manufacturing, its country of origin or its marketing authorization holder; c ) its history, including the records and documents relating to the distribution channels used. This definition does not include unintentional quality and is without prejudice to infringements of intellectual property rights."

b) It is, therefore, a broad definition which does not include unintentional quality defects. However, this Directive does not only cover the scope of the definition of counterfeit medicine, but it also includes relevant aspects in order to achieve a rational use of medicines and their distribution within the European Union that we will describe later.

The aforementioned European standards were subsequently incorporated into Spanish law. Thus, it was enacted Law 10/2013 ${ }^{25}$ of July 24 which also incorporates into the Spanish law Directive 2010/84/EU of the European Parliament and of the Council of 15 December 2010, on pharmacovigilance, and Directive 2011/62/ EU of the European Parliament and of the Council of 8 June 2011 on prevention of counterfeit medicines into the legal supply chain, amending Law 29/2006 of 26 July, on guarantees and rational use of medicines and medicinal products. Subsequently, a consolidated text enacted few months ago $^{26}$, defines counterfeit medicine in its article 2 (paragraph o) in terms of false representation in relation to:

1. - Its identity, including its packaging and labelling, its name or its composition as regard any of the ingredients including excipients and the strength of those

\footnotetext{
${ }^{25}$ Ley 10/2013 de 24 de julio de 2013, Boletín Oficial del Estado de 25 de julio de 2013, número 177, pp. 54488-54529.

${ }^{26}$ Real Decreto Legislativo 1/2015, de 24 de julio, por el que se aprueba el texto refundido de la Ley de garantías y uso racional de los medicamentos y productos sanitarios. Boletín Oficial del Estado de 25 de julio de 2015, núm. 177.
} 
ingredients;

2. - Its source, including its manufacturer, its country of manufacturing, its country of origin or its marketing authorisation holder; or

3. - Its history, including the records and documents relating to the distribution channels used.

We should note that this definition does not include, and from our point of view it is a significant fact, quality defects. Given this definition it is worth noting another definition, not included in this legislation, but relevant when analyzing counterfeit medicines. We refer to that product which appears in a country where it is not authorized, but in any other yes, this is what we have called above, according to the scientific literature, substandard medicine.

In addition, the abovementioned text, in Article 111 (paragraph c), considers very serious infringement the fact of manufacturing, importing, exporting, marketing, putting on the market, intermediating, distributing, dispensing and selling counterfeit medicines both in a directly and online way.

\section{Conclusions}

a) Counterfeiting medicines is a major problem worldwide that affects in varying degrees all countries. It is necessary an appropriate legislation and a clear definition concerning counterfeit medicine. Nowadays, we need to harmonize at international level the definition of counterfeit medicine, although there are already various attempts but it is required a local coordination to ensure an adequate regulation, control and research.

b) There are several proposals at both international and EU level to eradicate counterfeit medicines. In this paper we have analyzed European standards established to try to solve this emerging problem.

c) One of the solutions, besides legal harmonization, in view of the rise of these products, is promoting the technology of application accelerating different legal and administrative processes. Furthermore, it is necessary to apply more accurate controls on the import of active ingredients from third countries. 


\section{References}

La venta de medicamentos en Internet: riesgo de falsificaciones. Farmacéuticos, octubre de 2009. 350: 53-61.

BASANTE POL, R.; CASTILLO RODRÍGUEZ, C. Financiación de medicamentos: los aspectos jurídicos. Anales de la Real Academia Nacional de Farmacia. Madrid: Real Academia Nacional de Farmacia. 2013, 2(79): 294.

BOMBILLAR SÁENZ, F.M. Intervención administrativa y régimen jurídico del medicamento en la Unión Europea. Tesis doctoral. Granada: Ed. Universidad de Granada, 2010.

FIP Policy About Fake Drugs.

[Online]:http://www.fip.org/www/uploads/database_file.php?id=167\&table_id. [ Date of reseach: 21 de junio de 2015].

DÍEZ RIPOLLÉS, J. De la sociedad del riesgo a la seguridad ciudadana: un debate desenfocado. Revista Electrónica de Ciencia Penal y Criminología. 2005, (7 de enero): 4.

ESTEVA DE SAGRERA, J. Historia de la Farmacia. Los medicamentos, la riqueza y el bienestar. Barcelona: Ed. Masson, 2005.

FIGUERAS, A. Dificultades para el uso racional de medicamentos. Rev Peru Med Exp Salud Pública. Lima: Instituto Nacional de la Salud. 2009, 26(4): 549-552.

IMPACT. The View of Pharmaceutical Manufacturers. International Conference on Combating Counterfeit Drugs, 2007.

JARA, M. El negocio más repugnante, el marketing del miedo. El otro País, 2 de marzo de 2010 .

LLAMAZARES GÓMEZ, O. Reflexiones sobre la sociedad posindustrial. Revista de 
Obras Públicas. Madrid: ROP, 1981, 4: 265-269.

O’BRIEN, K.L.; SELANIKIO, G.D.; HECDIVERT, C., et al. Epidemic of Pediatric Deaths from Acute Renal Failure Caused by Diethylene Glycol Poisoning. JAMA. Nueva York: Journal of the American Medical Association, 1998, 279: 1175-1180.

World Health Organitation. The Rational Use of Drugs. Report of the Conference of Experts. (Nairobi, 25-29 November 1985). Geneve (Switzerland): WHO, 1987.

World Health Organitation. Implementation of WHO'S Revised Drug Strategy: Rational Use of Drugs; and WHO'S Action Program on Essential Drugs. World Health Assembly Resolution WHA47.13. Geneve (Switzerland): WHO, 1994.

World Health Organitation.(1995). Fake Drugs: Scourge on the System. WHO Drug Inf. Geneve (Switzerland): WHO.1995, 9: 127-129.

World Health Organitation Medicamentos falsificados. Pautas para la formulación de medios para combatir los medicamentos falsificados. Geneve (Switzerland) WHO, 1999.

World Health Organitation Organización Mundial de la Salud. Rational Use of Drugs. World Health Assembly Resolution WHA4 1.16. Ginebra (Suiza): WHO, 2009.

PINEL, J.; VARAINE, F.; MARCHANT, G. Des faux vaccins anti-meningocoque lords dúne epidemia de meningite au Niger. Med Maladies Infect Journal. Paris: SPILF, 1997, 27: 561-568.

PUERTO SARMIENTO, J. El Mito de Panacea. Compendio de Historia de la Terapéutica y de la Farmacia. Aranjuez (Madrid): Ed. Doce Calles S.L., 1997, pág. 10.

SILVA SÁNCHEZ, J. La expansión del Derecho penal. Madrid: Civitas Ediciones S.L., 2001, pág. 16. 


\section{Spanish Legislation Consulted}

Ley 10/2013 de 24 de julio de 2013, Boletín Oficial del Estado de 25 de julio de 2013, número 177 , pp. 54488-54529.

Real Decreto Legislativo 1/2015, de 24 de julio, por el que se aprueba el texto refundido de la Ley de garantías y uso racional de los medicamentos y productos sanitarios. Boletín Oficial del Estado de 25 de julio de 2015, núm. 177.

Ley 44/2003, de 21 de noviembre de 2003, de ordenación de las profesiones sanitarias. Boletín Oficial del Estado de 22 de noviembre de 2003, núm. 280.

Real Decreto Legislativo 1/2015, de 24 de julio, por el que se aprueba el texto refundido de la Ley de garantías y uso racional de los medicamentos y productos sanitarios. Boletín Oficial del Estado de 25 de julio de 2015, núm. 177.

\section{European Legislation Consulted}

Directiva 2001/83/CE del Parlamento Europeo y del Consejo de 6 de noviembre de 2001 por la que se establece un código comunitario sobre medicamentos para uso humano. Diario Oficial de la Unión Europea L 311 de 28de noviembre de 2001, p.67.

Directiva 2011/62/UE del Parlamento Europeo y del Consejo de 8 de junio de 2011 que modifica la Directiva 2001/83/CE por la que se establece un código comunitario sobre medicamentos de uso humano, en lo relativo a la prevención de la entrada de medicamentos falsificados en la cadena de suministro legal. Diario Oficial de la Unión Europea L 174/74 de 1 de julio de 2011.

Directrices de 19/03/2015, sobre prácticas correctas de distribución de principios activos para medicamentos de uso humano. Diario Oficial de la Unión Europea de 21 de marzo de 2015.

Artigo Recebido a 03 de outubro de 2015 I Aceite a 09 de março de 2016 